Cahiers $d u$ MONDE RUSSE

\section{Cahiers du monde russe}

Russie - Empire russe - Union soviétique et États indépendants

42/2-4 | 2001

La police politique en Union soviétique, 1918-1953

\title{
Razvitie sovetskih organov gosudarstvennoj bezopasnosti : 1917-1953 gg.
}

\section{Vladimir N.HAUSTOV}

\section{OpenEdition}

Journals

Édition électronique

URL : https://journals.openedition.org/monderusse/8458

DOI : 10.4000/monderusse. 8458

ISSN : $1777-5388$

\section{Éditeur}

Éditions de l'EHESS

\section{Édition imprimée}

Date de publication : 1 avril 2001

Pagination : 357-374

ISBN : 2-7132-1398-3

ISSN : $1252-6576$

Référence électronique

Vladimir N.HAUSTOV, «Razvitie sovetskih organov gosudarstvennoj bezopasnosti : 1917-1953 gg. », Cahiers du monde russe [En ligne], 42/2-4 | 2001, mis en ligne le 01 janvier 2007, consulté le 02 septembre 2022. URL : http://journals.openedition.org/monderusse/8458 ; DOI : https://doi.org/ $10.4000 /$ monderusse. 8458 
chercher : repérer : avancer

Cet article est disponible en ligne à l'adresse :

http://www.cairn.info/article.php?ID REVUE=CMR\&ID NUMPUBLIE=CMR 422\&ID ARTICLE=CMR 4220357

Razvitie sovetskih organov gosudarstvennoj bezopasnosti : 1917-1953 gg

par Vladimir N. HAUSTOV

Editions de I'EHESS | Cahiers du monde russe

2001/2-3-4 - Vol 42

ISSN 1252-6576 | ISBN 2713213983 | pages 357 à 374

Pour citer cet article :

-N. HAUSTOV V., Razvitie sovet skih organov gosudarstvennoj bezopasnosti : 1917-1953 gg, Cahiers du monde russe 2001/2-3-4, Vol 42, p. 357-374.

Distribution électronique Cairn pour les Editions de l'EHESS.

(C) Editions de l'EHESS. Tous droits réservés pour tous pays.

La reproduction ou représentation de cet article, notamment par photocopie, n'est autorisée que dans les limites des conditions générales d'utilisation du site ou, le cas échéant, des conditions générales de la licence souscrite par votre établissement. Toute autre reproduction ou représentation, en tout ou partie, sous quelque forme et de quelque manière que ce soit, est interdite sauf accord préalable et écrit de l'éditeur, en dehors des cas prévus par la législation en vigueur en France. Il est précisé que son stockage dans une base de données est également interdit. 


\title{
РАЗВИТИЕ СОВЕТСКИХ ОРГАНОВ ГОСУДАРСТВЕННОЙ БЕЗОПАСНОСТИ: 1917-1953 ГГ.
}

\author{
Партийное руководство органами госбезопасности
}

Органы государственной безопасности в исследуемый период являлись составной частью исполнительной ветви власти в СССР. Их деятельность в полной мере зависела от того, какие задачи возлагались на них высшими органами законодательной и исполнительной власти. Формально в официальных документах, которых было не так много, роль органов государственной безопасности определялась в решениях ЦИК (с 1938 года Верховного Совета СССР), постановлениях и решениях партии и правительства. Это находило отражение в основных правовых актах, регламентировавших деятельность органов государственной безопасности, таких как положение о ГПУ РСФСР (1922 г.), принятое постановлением ВЦИК от 6 февраля 1922 года, или положение об образовании НКВД СССР, принятое постановлением ЦИК от 10 июля 1934 года.

Фактически с февраля 1922 года было закреплено положение, при котором органы государственной безопасности стали находиться под полным контролем правящей коммунистической партии. 15 февраля 1922 года на заседании политбюро ЦК РКП(б) было принято решение:

«Возложить на личную ответственность т. Енукидзе наблюдение за тем, чтобы ни один вопрос, связанный с Госполитуправлением не поступал на разрешение Президиума ВЦИКа без предварительного согласования с Политбюро.»

На заседаниях Политбюро и Секретариата ЦК ВКП(б) принимались решения об организации и структуре, финансировании, назначении руководителей центра и областных управлений, наиболее важные ведомственные нормативные акты. Затем эти решения дублировались высшими органами

1. Архив Президента Российской Федерации, ф. 3, оп. 58, д. 2, л. 25. Далее АП РФ.

Cahiers du Monde russe, 42/2-3-4, Avril-décembre 2001, pp. 357-374. 
власти и управления, как правило, в виде секретных решений и постановлений.

До принятия в период М. С. Горбачева в 1990 году закона «Об органах государственной безопасности в СССР» и упразднения КГБ СССР в 1991 году, не подвергался сомнению основной принцип их деятельности, сформулированный в феврале 1919 года о том, чрезвычайные комиссии действуют «как прямые органы партии под ее директивами и под ее контролем» ${ }^{2}$.

В советской и зарубежной исторической литературе отмечается, что базовым правовым документом, определявшим деятельность органов государственной безопасности в 1920-1950-е годы являлось положение о Государственном политическом управлении от 6 февраля 1922 года. Однако существовало секретное положение об НКВД, которое было принято только на заседании политбюро от 15 июля 1934 года. В нем были определены права и полномочия НКВД, основные оперативные средства, которые использовали органы госбезопасности. В разделе $\mathrm{V}$ положения об НКВД СССР отмечались средства, необходимые для выполнения возложенных на НКВД задач:

«1. Осведомление и розыск, наблюдение, арест, выемка, обыск. 2. Агентурное наблюдение за преступными или подозрительными группами и организациями. 3. Регистрация уличенных, заподозренных в преступной деятельности лиц и их дел. 4. Учет и приговоренных и сосланных и осуществление специального надзора за ними. 5. Просмотр почтовой, телеграфной и иной корреспонденции.» ${ }^{3}$

Основополагающее положение являлось только партийным решением, не было утверждено органами законодательной и исполнительной власти, но являлось решением, на основе которого строилась вся деятельность. Так, 25 января 1935 года Прокурор СССР И. Акулов направил Сталину сообщение, в котором писал:

«15 января 1935 года в газете Известия опубликована заметка о том, что комиссия советского контроля предложила наркомвнуделу выслать из Москвы представителей ряда организаций, занимавшихся противозаконной деятельностью. Из заметки вытекает, будто наркомвнудел является техническим исполнителем постановлений комиссии. Опубликование такого рода постановлений не только противоречит закону, но и создает весьма нежелательное впечатление о множественности административных органов, имеющих право ссылать и высылать. Прокуратура просит дать бюро комиссии советского контроля соответствующие указания.» 4

Прокурор СССР упоминал раздел V положения об НКВД СССР, в соответствии с которым только Наркомату внутренних дел предоставлялось

2. Из истории ВЧК. Сборник документов, М., 1958, с. 250.

3. АП РФ, ф. 3, оп. 58, д. 5, лл. 73-74

4. АП РФ, ф. 3, оп. 58, д. 5, л. 122. 
право «высылки за пределы Союза ССР иностранных граждан, проживание которых в СССР будет признано нежелательным», а также «ссылка и заключение в исправительно-трудовые лагеря на срок до 5-ти лет через особое совещание лиц, признанных социально-опасными».

Таким образом, важнейший документ, в котором регламентировалось правовое положение, направления оперативной деятельности, формы и методы работы был принят в виде секретного решения Политбюро ЦК ВКП(б).

С момента возникновения Всероссийской чрезвычайной комиссии на руководящие должности (в губернские чрезвычайные комиссии) назначались члены партии, вступавшие в нее в дореволюционный период, что должно было свидетельствовать об их глубокой преданности и верности идеалам революции. Это было одно из направлений укрепления влияния правящей партии в органах госбезопасности. В октябре 1927 года накануне 10-й годовщины Октябрьской революции руководство ОГПУ направило на места указание о необходимости «продвижения на более ответственнур работу» тех членов партии, которые вступили в нее до революции ${ }^{5}$. Наибольший авторитет в ОГПУ-НКВД имели сотрудники, которые являлись членами партии с дореволюционным стажем. К ним относились Г. Бокий начальник спецотдела, Т. Дерибас - начальник УНКВД по Дальневосточному краю, В. Балицкий — председатель ГПУ Украины, Наркомвнудел УССР и другие.

Руководители органов госбезопасности на местах являлись членами бюро райкомов и обкомов партии, составной частью номенклатуры соотвествующего уровня. Партийные указания воспринимались ими только как указания «директивных органов», которые подлежали исполнению, а не обсуждению. Это были отношения не столько взаимодействия, сколько починения. Основные направления работы органов госбезопасности обсуждались на заседаниях бюро партийных органов.

После убийства С. М. Кирова на активе сотрудников органов госбезопасности в феврале 1935 года впервые был резко поставлен вопрос о некотором изменении роли руководителей НКВД. На протяжении 1920-1930-х годов в процессе проведения различных хозяйственно-политических мероприятий сотрудники органов госбезопасности выступали в роли уполномоченных соответствующих партийных органов. В новом качестве секретаря ЦК ВКП(б) и председателя Комиссии партийного контроля Н. Ежов, которому было поручено контролировать работу НКВД, критиковал работу начальников УНКВД Свердловской области И. Решетова и Сталинградского края Г. Раппопорта. На февральском 1935 года совещании оперативного состава Главного управления госбезопасности Ежов, выступавший с основным докладом, отмечал:

«Они занимались работой ЭКУ и превратились в подсобный орган уральского обкома и выполняли поручения по всяким делам, имеющим и не

5. Центральный архив Федеральной службы безопасности РФ. Далее ЦА ФСБ. ф. 2, оп. 10, д. 190, л. 351. 
имеющим отношения к контрреволюции. Я предупреждал Решетова. Это очень хорошо, что мирно живет с обкомом, помогает обкому. Все это вещь очень хорошая. Может быть, вы почетными людьми будете. Вас будут выбирать, хвалить и т.д. Но с точки зрения чекистской работы - провалитесь.» 6

В ущерб оперативной работе они превратили свои управления в «подсобные органы обкома», выступали в роли уполномоченных в ходе посевной и заготовительной кампании. Интересно то, что Н. Ежов не отрицал необходимость оказания помощи партийным органам, но советовал не забывать основной работы, которая была возложена на НКВД 7 .

Определенный перелом наступил с приходом к руководству органами госбезопасности Л. Берия. В октябре 1940 года он докладывал секретарю ЦК ВКП(б) Г. Маленкову, что обком ВКП(б) в Тамбове назначает оперработников управления НКВД уполномоченными по хлебозаготовкам и отрывает их от оперативной работы. Одновременно он обратился и к секретарю Тамбовского обкома партии, в котором отмечал, что перед начальником областного управления стоят другие задачи. Впервые он выдвигал перед партийным руководителем идею об освобождении сотрудников органов госбезопасности от выполнения несвойственных им функций ${ }^{8}$, в определенной мере отстаивал независимость в практической деятельности. Это происходило в период после массовых репрессий 1937-1938 годов, когда резко усилился контроль партийного аппарата в центре и на местах за деятельностью органов госбезопасности.

Если рассматривать взаимоотношения партии и органов госбезопасности на протяжении 1917-1953 годов, то только в годы массовых репрессий 1937-1938 годов сотрудникам НКВД было позволено без ограничений арестовывать и, используя физические методы, выбивать любые показания у партийных руководителей.

К середине 1930-х годов сложился определенный порядок в производстве арестов. В период с начала 1930-х годов Политбюро ЦК приняло ряд решений о необходимости согласования для НКВД арестов иностранцев с Народным комиссариатом иностранных дел, транспортных работников с Народным комиссариатом путей сообщения, военнослужащих с Наркоматом обороны. Согласие на арест давал, как правило, нарком. Теперь же принималось совместное партийно-советское постановление, в котором расширялся круг специалистов в различных отраслях народного хозяйства, что создавало дополнительные трудности для НКВД. В определенной мере это было свидетельство либерализации карательной политики, стремление ограничить роль НКВД в производстве арестов среди профессиональной элиты служащих советского общества. И. Сталин создал систему совместной ответственности при арестах номенклатурных работников, специалистов, военнослужащих, высшего, старшего и среднего начальствующего

6. ЦА ФСБ, ф. 3, оп. 2, д. 12, лл. 16-17.

7. Там же, д. 8 , лл. $16-18$.

8. Там же, оп. 7, д. 31, лл. 86-88. 
состава. В соответствии с постановлением СНК СССР и ЦК ВКП(б) «О порядке производства арестов» от 17 июня 1935 года для арестов указанных категорий населения необходимо было получить: 1) санкцию прокурора; 2) согласие соответствующего наркома; 3) согласие партийного органа, начиная с районного звена в случае ареста рядового коммуниста. Само постановление являлось свидетельством определенной дискриминации в отношении подавляющей части населения СССР, для ареста которых нужна была только санкция прокурора. Резко возрастала роль Н. Ежова как председателя Комиссии партийного контроля, поскольку аресты коммунистов, занимавших руководящие должности в наркоматах и центральных учреждениях, были возможны по согласованию с председателем КПК. В это время Н. Ежов получает значительные полномочия, когда в его руках была сосредоточена власть как руководителя основного карательного органа страны и контрольного органа партии. В период «генеральной чистки» советского общества в 1937-1938 годах при назначении новых начальников управлений НКВД он рекомендовал им смело выступать на партийных активах, разоблачать «врагов народа», подчеркивая, что все необходимые санкции в центре будут получены. Так, начальник УНКВД Западной области, а затем нарком НКВД БССР А. Л. Наседкин указывал, что в процессе подготовки спецоперации в 1937 году по латышам Ежов и его заместитель Фриновский заинтересовались возможностью провести массовые аресты в рамках проведения операции по инонациональностям. Он заявил, что «согласует в ЦК ВКП(б) арест не менее 1,5 тысяч человек», и через два дня Наседкин получил такое разрешение. Одновременно в аппарате НКВД была подготовлена почтотелеграмма о репрессировании лиц латышской национальности 9 .

Определенные спецсообщения НКВД, главным образом, о негативных проявлениях в различных областях народного хозяйства Ежов, став наркомом, иногда направляет в Комиссию партийного контроля для расследования и принятия мер только в партийном порядке.

Нельзя не отметить, что в отличие от других советских ведомств, деятельность которых подвергалась критике в печати по итогам проверок КПК, работа Наркомата внутренних дел и особенно Главного управления госбезопасности (ГУГБ) не подлежала публичному обсуждению. На оперативных совещаниях Ежов неоднократно подчеркивал, что «чекист менее подконтролен в своих действиях, по сравнению с работником другого аппарата» ${ }^{10}$.

В разгар массовых репрессий в апреле 1938 года, получая от начальников областных управлений ходатайства об аресте лиц, подпадавших под действие постановления от 17 июня 1935 года, Н. Ежов или М. Фриновский направляли на места следующие шифртелеграммы: «Арест с НКПС [Народный комиссариат путей сообщения - В. Х.] согласован», «арест с

9. ЦА ФСБ, Архивное следственное дело Н-15301, т. 14, лл. 337-340.

10. ЦА ФСБ, ф. 3 , оп. 5, д. 13. л. 4. 
НКОП [Народный комиссариат оборонной промышленности] согласован», «арест с НКО [Народный комиссариат обороны] согласован.» 11

Аресты номенклатурных работников, кандидатуры которых утверждались в ЦК ВКП(б), осуществлялись только с санкции Сталина. Действие постановления от 17 июня 1935 года объясняет наличие списков на аресты, подписанные Сталиным, Кагановичем, Молотовым и другими руководителями партии и государства.

То есть для ареста номенклатурных работников Ежов не обладал властью и обращался за разрешением на арест к наркомам и Сталину. В этой связи можно верить арестованному в 1951 году министру государственной безопасности В. Абакумову, который отрицал свою личную инициативу в арестах ряда генералов ВВС (Военно-воздушные силы), работников авиационной промышленности. Он подчеркивал, что получил на это указание от Сталина.

Однако, обладая огромным влиянием, нарком госбезопасности, учитывая маниакальную подозрительность Сталина, мог способствовать и способствовал аресту высокопоставленных чиновников партийного, советского, хозяйственного аппарата, военнослужащих Красной Армии.

Ежов пытался стать теоретиком, в практике массовых репрессий 1937 1938 годов обосновывая тезис о формировании в стране огромного разветвленного заговора. На июньском 1937 года Пленуме ЦК ВКП(б) он выдвигал идею об образовании антисоветского «центра центров». Развивая мысль Сталина об объединении всех враждебных советскому государству сил, Ежов рисовал схему, в которой выделял в качестве ядра центра группу Бухарина и примыкавших к ней несколько других центров, в том числе и военных заговорщиков в НКВД ${ }^{12}$.

Такую же схему использовали его подчиненные. Например начальник Особого отдела (военная контрразведка) в этот период кроме центрального «военно-троцкистского заговора» (Тухачевский и др.) сфабриковал «военно-фашистский латышский заговор» (Вацетис, Алкснис и др.), «военно-политический заговор» (Смирнов, Булин и др.), «военно-эсеровский заговор» (Белов, Грязнов и др.), «военно-монархический заговор» (Верховский, Баторский и др.).

Нередко обращения Ежова были безрезультатными. Два раза он обращался к наркому К. Ворошилову, чтобы тот дал согласие на арест одного из своих заместителей, Хрулева. В третий раз он обратился к Сталину и тоже не получил согласия.

Исследователи, внимательно изучавшие проблему взаимоотношений между обкомами партии и управлениями НКВД, отмечают независимость в действиях и элементы критики со стороны партийного руководства в адрес руководителей НКВД разных уровней даже в период массовых репрессий.

Среди многих причин приостановления массового террора нельзя не отметить и резкое недовольство значительной части нового поколения пар-

11. Там же, оп. 5, д. 1541, лл. 30, 110, 254.

12. Там же, оп. 4 , д. 29, л. 246. 
тийных чиновников репрессиями в их среде. Сталин получал многочисленные свидетельства. Так, в октябре 1938 года Сталину было направлено очередное спецсообщение, в котором сообщалось о реакции на аресты первого секретаря Энгельсского горкома партии Саратовской области. Он возмущался ненормальным режимом работы, когда «пересажали» третий состав райкома и обкома ${ }^{13}$.

После периода большого террора правящая партия проявила наибольшую заботу об ограждении нового слоя партаппарата от органов госбезопасности, сотрудникам которых было позволено арестовывать партийных работников всех рангов. Для усиления контроля за деятельностью ГУГБ НКВД СССР и его управлений на местах еще 20 сентября 1938 года Политбюро ЦК ВКП(б) приняло решение об учете, проверке и утверждении в ЦК ВКП(б) всех ответственных работников центрального аппарата НКВД до начальника отделения, а на местах до начальника горрайотделения. В развитие этого решения 14 ноября в бюро горкомов, обкомов, крайкомов, ЦК нацкомпартий за подписью Сталина было направлено постановление, в котором бюро партийных органов обязаны были проверить всех ответственных работников местных органов НКВД. Рекомендовалось при этом провести «личное ознакомление с ними, не дожидаясь при этом представления этих работников начальником НКВД на утверждение обкома, крайкома, ЦК нацкомпартии». Решением бюро соответствующего партийного органа утверждались или отклонялись кандидатуры, представленные начальником УНКВД. Первые секретари должны были затем докладные записки об учете, проверке и утверждении ответственных работников систематически направлять в ЦК ВКП(б). Была поставлена задача очистить органы НКВД от «всех враждебных людей обманным путем проникших в органы НКВД, от лиц не заслуживающих политического доверия» ${ }^{14}$. В отношении остальных работников местных органов НКВД, не утверждаемых ЦК ВКП(б), также предусматривалось проведение проверки. Одновременно был установлен порядок, при котором прием и освобождение оперативного работника, переброска его из одного района, области в другие разрешались с санкции соответствующего партийного органа. Таким образом, резко усиливалось влияние партийных органов на кадровый состав органов госбезопасности как через значительное увеличение количества штатных сотрудников, утверждаемых в ЦК ВКП(б), так и через контроль за зачислением на службу новых работников. Ранее на основе циркуляра ГУГБ НКВД СССР от 27 июля 1936 года прием осуществлялся, минуя партийные органы. Отныне местные УНКВД, направляя в центр докладные записки о состоянии работы с кадрами, постоянно отмечали взаимодействие с партийной властью. Так, в июне 1940 года начальник УНКВД Саратовской области указывал, что из 250 человек номенклатуры обкома утверждение прошли 232 человека ${ }^{15}$.

13. Там же, оп. 5, д. 82, л. 361.

14. АП РФ, ф. 3 , оп. 58 , д. 6, лл. 80-82.

15. ЦА ФСБ, ф. 3 , оп. 7, д. 763, л. 129. 
Представляет интерес и известная телеграмма, направленная в январе 1939 года Сталиным в ходе проверки органов НКВД секретарям ЦК нацкомпартий, крайкомов и обкомов о правильности и целесообразности применения физического воздействия органами НКВД как в период массовых репрессий, так и в виде исключения в дальнейшем. Партийные органы на местах, изучив положение дел, стали требовать привлечения к уголовной ответственности значительной части оперсостава. Секретарь Смоленского обкома, например, настаивал на аресте многих работников УНКВД, так как получал многочисленные жалобы от освобожденных жителей города о применении к ним физических методов воздействия. Своей телеграммой Сталин фактически взял под защиту сотрудников НКВД, не желая дискредитировать организацию, которая являлась опорой его власти и выполняла указания Политбюро ЦК ВКП(б) в годы большого террора.

Для повышения самостоятельности и независимости партийного аппарата от органов государственной безопасности И. Сталин лично отредактировал представленный ему Л. Берия приказ о запрещении привлекать к сотрудничеству номенклатурных, партийных, советских, профсоюзных работников. Фактически органам госбезопасности было запрещено вести среди этой социальной прослойки оперативную работу. Таким образом, господствующее воздействие правящей коммунистической партии было закреплено ведомственными нормативными актами, что значительно укрепило положение партноменклатуры и ее относительно спокойное существование в советском обществе в период правления И. Сталина. Хотя по личному указанию Сталина мог быть арестован любой руководитель.

Изменение политического курса в политике правящей партии находило прямое отражение в деятельности руководителей спецслужбы. Л. Берия, став наркомом внутренних дел, в изменившихся условиях стал инициатором ряда реорганизаций, способствовавших более эффективной деятельности органов государственной безопасности. В декабре 1938 года в докладной записке на имя Сталина он обосновал необходимость создания следственной части, которая отсутствовала в НКВД. «Мы решили [...] организовать одну общую следственную часть НКВД СССР, в которой будет сосредоточено ведение следствия по делам всех оперативных отделов и управлений НКВД.» ${ }^{16}$ Создание самостоятельного следственного подразделения позволяло ограничить произвол и беззаконие в оперативной работе. Берия активно способствовал выделению из НКВД оперативных управлений (ГУГБ, ГЭУ - Главное экономическое управление, ГТУ - Главное транспортное управление), когда в докладной записке Сталину в январе 1941 года отмечал, что хозяйственная деятельность наркомата достигла огромных объемов и ослабляла разведывательную и контрразведывательную деятельность, а также функцию политической полиции ${ }^{17}$. В феврале 1941 года был образован НКГБ СССР.

16. АП РФ, ф. 3, оп. 58, д. 6, л. 23.

17. ЦА ФСБ, ф. Зос, оп. 8, д. 6, лл. 8-10. 
Однако НКВД СССР в период, когда его возглавлял Л. Берия, был орудием советского правительства. Конечно, это не была чудовищная по своим последствиям политика «генеральной чистки» советского общества в 1937-1938 годах при Ежове. Но роль органов госбезопасности в «советизации» республик Прибалтики, западных областей Украины и Белоруссии в 1939-1941 годах напоминала эту политику. Масштабы массовых депортаций народов СССР в предвоенный период, в годы Великой Отечественной войны и послев нее по своим последствиям сравнимы с социальными потрясениями периода массовой коллективизации.

\section{Экономика и органы госбезопасности}

Специфика создания и развития мощного экономического потенциала СССР в 1920-1950-е годы связана со значительным использованием аппарата органов ВЧК-ОГПУ-НКВД-МГБ в решении самых разнообразных задач хозяйственного строительства.

Фактически это была совершенно новая функция, вытекавшая из особенностей развития советской экономики. Правящая партия использовала органы госбезопасности как один из важнейших инструментов репрессивного управления в условиях форсированного создания экономического потенциала.

Задачи экономического отдела определялись в положении о Главном управлении государственной безопасности НКВД СССР от 1934 года как

«1. борьба с вредительством, попытками диверсий агентов иностранных разведок и контрреволюционных элементов, изменой родине, шпионажем и другими государственными преступлениями в народном хозяйстве СССР, 2. борьба с хищениями социалистической собственности, 3. борьба с должностными преступлениями.» 18

В переработанном положении о ГУГБ НКВД СССР в 1938 году пункты второй и третий уже не указаны, но более развернуто дано первое положение ${ }^{19}$. В предвоенные годы роль экономических подразделений усиливается и в 1938 году наряду с ГУГБ НКВД СССР будет образовано Главное экономическое управление НКВД СССР.

В течение 1920-1950-х годов постепенно происходил переход от использования органов безопасности как орудия насилия к усилению их роли как органов контроля, проверки исполнения решений правительства и информирования высшего руководства о ходе выполнения важнейших заданий.

Фальсифицированные процессы конца 1920 - начала 1930-х годов призваны были оправдать срывы плановых заданий происками буржуазных специалистов, «вредительством» в различных отраслях народного хозяйства.

18. АП РФ, ф. 3, оп. 58, д. 4, л. 174.

19. ЦА ФСБ, ф. 3, оп. 4 , д. 2, л. 2. 
Однако уже со второй пятилетки количество арестованных по данному обвинению резко сокращается. Если в 1934 году по обвинению во вредительстве было арестовано почти 15 тысяч человек, то в 1940 около 1,5 тысяч. Репрессии не могли повлиять на ликвидацию объективных трудностей в промышленности и сельском хозяйстве. Кризис привлечения к уголовной ответственности за «вредительство» невольно ярко выразил начальник УНКВД по Омской области Э. Салынь. В докладной записке наркому Г. Ягоде он писал в 1935 году: «Исходя из массовости аварий и крушений, мы не могли пойти по линии массового привлечения к уголовной ответственности по каждому свершившемуся крушению или аварии.» 20

Создание достаточно мощного экономического потенциала в результате трех предвоенных пятилеток в течение 1928-1941 годов объективно способствовало тому, что обвинения во вредительстве постепенно сокращаются. Так, за весь период Великой Отечественной войны 1941-1945 годов было арестовано за вредительство 2724 человека из 452292 человек, арестованных территориальными органами НКВД-НКГБ СССР 21.

Глобальные социально-экономические преобразования сопровождались усилением насильственных методов решения проблем. ОГПУ совместно с частями Красной Армии подавляли крестьянские восстания в период коллективизации, организовывали аресты, переселения и высылки крестьян.

Укрепление колхозов также было связано с усилением репрессивных мер. В созданных в 1933 году политотделах МТС и совхозов были по решению политбюро ЦК ВКП(б) учреждены должности заместителей начальников политотделов по политической работе - штатные сотрудники ОГПУ. В их задачи в соответствии с приказом ОГПУ № 0017 от 25 января 1933 года входит борьба с контрреволюционными проявлениями в МТС и совхозах, выявление контрреволюционных и кулацких группировок, их вредительской деятельности, охрана социалистической собственности, освещение политико-морального и производственно-хозяйственного состояния МТС и совхозов 22 . В процессе деятельности заместителей начальников политотделов МТС и совхозов сразу выявились трудности, заключавшиеся в том, что многие из них «целиком переключились на хозяйственную работу» и «превратились в придаток аппарата МТС». Поэтому в приказе ОГПУ № 0045 от 3 февраля 1933 года вновь их главная задача определялась в «решительной борьбе с контрреволюцией» 23.

Двойственное положение заместителя начальника политотдела заключалось в том, что, с одной стороны, они в соответствии с указаниями совместного циркуляра ОГПУ и Наркомзема от 3 февраля 1933 года целиком подчинялись начальнику политотдела, выполняли их задания. С другой стороны, они сохраняли полную самостоятельность в оперативной работе.

20. Там же, оп. 2 , д. 729 , л. 4.

21. Там же, ф. 4, оп. 4, д. 693, л. 54.

22. Там же, ф. 66, оп. 1 т., д. 56, л. 3.

23. Там же, л. 5. 
К лету 1933 года был обобщен первый опыт деятельности заместителей начальников политотделов МТС и совхозов, который показал, что существовали глубокие противоречия между начальником политотдела и его заместителем по линии ОГПУ, являвшимся вторым заместителем. Первый заместитель отвечал за партийно-массовую и организационную работу. Главное противоречие заключалось в том, что заместитель по линии ОГПУ стремился к полной самостоятельности и независимости от начальника. В совместном июльском 1933 года приказе ОГПУ и Наркомата земледелия подчеркивалось, что «зам. нач. политотдела МТС и совхозов целиком подчинен нач. политотдела» 24 . Роль сотрудника ОГПУ была резко ограничена в связи с поворотом политики государства в деревне после массовой коллективизации. В инструкции ЦК ВКП(б) и СНК СССР «Всем партийносоветским работникам и всем органам ОГПУ, суда и Прокуратуры» от 8 мая 1933 года отмечалось, что «массовые репрессии и аресты в деревне становятся явно политически вредными и опасными». В конечном итоге изменение карательной политики в деревне явилось одной из причин ликвидации института политотделов МТС и совхозов.

На органы госбезопасности возлагались задачи по контролю над деятельностью наиболее важных государственных учреждений. Так например, после создания Главконцесскома, который руководил всей концессионной работой, т.е. привлечением иностранного капитала в советскую экономику, Экономическому управлению ОГПУ было поручено вести общее наблюдение за этим ведомством, а также давать свои рекомендации при назначении на должности. Исполняющий обязанности управделами концесскома при СНК РСФСР 4 ноября 1927 года обратился к начальнику отдела ЭКУ ОГПУ с просьбой дать рекомендации о приеме на работу ряда сотрудников. В течение 30-х годов будут выделены более ста промышленных предприятий оборонной промышленности, где в соответствии с постановлением ЦК ВКП(б) будет введена должность помощника директора по найму рабочей силы, на которую назначался сотрудник НКВД. Главная задача его заключалась в проверке всего личного состава, составлявшего более 469 тысяч инженеров, техников, рабочих. По итогам чисток, которые были закончены к середине 1936 года, 27 тысяч человек были уволены, а 11 тысячам отказано в приеме на работу 25 . Советские граждане увольнялись на основе признаков социальной и национальной принадлежности.

В наиболее напряженные периоды органы госбезопасности привлекались Советским государством и к решению проблемы сохранения и распределения собранного урожая зерновых. На основании совместного приказа НКВД СССР и Комитета заготовок при СНК СССР комендантами элеваторов и заготпунктов «Заготзерно» назначались сотрудники НКВД. В совместном приказе этих ведомств от 27 июля 1934 года указывалось:

24. Там же, л. 19.

25. Там же, ф. 3, оп. 2, д. 900, л. 129. 
«Коменданты элеваторов и заготпунктов подчиняются краевым, областным управлениям НКВД и работают на правах помощников заведующих элеваторами и заготпунктами, и ведут специальную работу по охране зерна, борьбе с хищениями и потерями зерна и руководят сторожевой и противопожарной охраной.» 26

При областных управлениях были введены должности начальника инспекции резервов Комитета резервов, на которого была возложена задача строжайшего учета и контроля за сохранностью и расходованием мобилизационных запасов в стране. Так, старший инспектор Балаковского оперсектора НКВД Н. В. Карийский, допустивший авансирование хлебопродуктами в апреле за май 1934 года по городу Балакову, был приговорен к двум годам тюремного заключения ${ }^{27}$. Таким образом, советское руководство создало жесткую систему по охране и распределению зерновых и других сельхозпродуктов, сдаваемых государству и составлявших значительную часть валютных поступлений страны.

По сравнению с периодом сплошной коллективизации, когда органы государственной безопасности являлись одним из инструментов ее осуществления, их участие в хозяйственной жизни советской деревни во второй половине 30-х годов стало более ограниченным. Однако им отводилась та же роль карательного органа в ходе переустройства сельского хозяйства.

В директивных указаниях НКВД-МГБ СССР нормальная работа промышленных предприятий ставилась в прямую зависимость от деятельности соответствующих отделов, управлений органов государственной безопасности. В случае невыполнения планов, аварий, которые приводили к остановке предприятий, репрессиям подвергались сотрудники оперативных отделов. В апреле 1935 года, в связи с выходом из строя из-за пожара цеха ярославского резино-асбестового комбината был отстранен от должности и предан суду начальник горотдела НКВД «за развал оперативной работы» 28 .

Охватить своим воздействием все отрасли народного хозяйства по мере создания мощного экономического потенциала было для органов государственной безопасности неосуществимой задачей. Начиная с конца 1930-х годов основное внимание экономических подразделений НКВД-НКГБ-МГБ было сосредоточено на наиболее важных отраслях, прежде всего оборонного комплекса. Многие решения Политбюро ЦК ВКП(б), постановления ЦК ВКП(б) и СНК СССР принимались на основе информации, предоставленной органами госбезопасности. Так, в сентябре 1940 г. по итогам работы ведомственной комиссии о результатах расследования положения на заводах Наркомата боеприпасов Сталин скептически оценил их выводы. В записке наркому государственного контроля он указывал: «Т. Мехлис! Комиссия т. Сергеева едва ли заслуживает большого доверия. Хорошо бы вам совместно с Берия послать для расследования группу в 3-4 человека». По итогам работы совместной комиссии наркоматов госконтроля и вну-

26. Там же, ф. 66, оп. 1, д. 303, лл. 102-103.

27. Архив УФСБ по Воронежской области, ф. 2лс, д. 14, л. 104.

28. ЦА ФСБ, ф. 66, оп. 1, д. 332, л. 152. 
тренних дел Берия подготовил обобщающий документ, который был принят Политбюро ЦК ВКП(б) 11 ноября 1940 года в качестве закрытого постановления «О результатах проверки наркомата боеприпасов» 29 .

В 1946 году дело о работниках авиационной промышленности и ВВС Советской армии Худякове, Шахурине и других было начато с представления В. Абакумовым информации сотрудников контрразведки «Смерш» Сталину о поставке некачественных истребителей в армию ${ }^{30}$. Расследование органами госбезопасности данных фактов привело как к арестам ряда руководящих работников, так и к принятию постановления партии и правительства по улучшению работы предприятий авиапромышленности.

Таким образом, прослеживается, как закономерность стремление высшего партийного руководства решать некоторые важнейшие экономические проблемы с помощью органов государственной безопасности. В послевоенные годы одной из таких проблем стала проблема, связанная с разработкой ядерного оружия.

\section{Органы госбезопасности как органы тайной политической полиции}

Господство одной политической партии, которая стала правящей и беспощадно боролась с любыми оппозиционными силами, привело, в конечном счете, к подавлению любого инакомыслия в обществе. Органы госбезопасности на протяжении всего исследуемого периода выполняли функцию тайной политической полиции. Высшее руководство страны после окончания гражданской войны не только не утвердило в сознании миллионов людей идеологию гражданского мира, а, наоборот, встало на путь искусственного разжигания «классовой борьбы» в стране. В первую очередь Секретнополитический отдел, а также Экономический, Транспортный отделы осуществляли политический розыск, часто исходя из принципа бывшей социальной, партийной и национальной принадлежности граждан.

Высшее руководство страны использовало спецслужбу для преследования «социально чуждых», «социально опасных элементов», «бывших людей». В конечном счете, эти понятия трансформировались в понятие «враг народа». В проекте положения о ГУГБ НКВД СССР в 1938 году одной из основных задач спецслужбы назвались «своевременное, быстрое и исчерпывающее выявление и ликвидация врагов народа из остатков ликвидированных классов и буржуазных перерожденцев, предотвращение и пресечение их антисоветской работы» ${ }^{31}$.

Существовавший в 1930-1940-е годы списочный учет антисоветского элемента в основе своей базировался на принципах бывшей партийной,

29. АП РФ, ф. 3, оп. 58, д. 343а, лл. 155-164.

30. Там же, д. 311, л. 66.

31. ЦА ФСБ, ф. 3, оп. 4 , д. 2 , л. 2. 
социальной принадлежности, а также национальности и идейных воззрений человека. Из 18 категорий населения, включенных в списочный учет на основе приказа, принятого в 1939 году, 6 категорий объединяло понятие «бывшие». К ним относились: «бывшие люди», то есть представители царской администрации, дворяне, помещики, купцы (1); все бывшие кулаки (2); бывшие участники восстаний (3); бывшие жандармы, полицейские, тюремщики (4); бывшие офицеры (царские, белые, петлюровские и др.) (5); бывшие политбандиты и добровольцы Белой армии и др. (6). Исходя из партийной принадлежности постановке на учет подлежали еще 3 категории: члены так называемых антисоветских политических партий (7), националшовинистических антисоветских партий (8) и лица, исключенные из ВКП(б) за антисоветские проступки (9). Ставились на учет лица, отбывшие наказание за контрреволюционные преступления (10) и члены семей, осужденных за контрреволюционные преступления к ВМН и на срок более 10 лет, в возрасте от 16 до 60 лет (11).

Пять категорий рассматривались в качестве потенциальной базы иноразведок: немцы, поляки, японцы, китайцы, корейцы и др., проявлявшие националистические настроения (12). Сюда включались все перебежчики, политэмигранты, репатрианты и контрабандисты (13), все иноподданные, а также советские граждане, служащие и служившие в инопредставительствах (14), лица, имевшие письменные связи с заграницей, посольствами, а также эспирантисты и филателисты (15), лица, въехавшие в СССР в массовом порядке (харбинцы и др.) (16). Преследованиям подвергались церковники, сектанты и религиозный актив (17), члены тайных мистических обществ и кружков, масоны, теософы, богословы и т.п. (18) ${ }^{32}$.

Однако не соответствует действительности утверждение, что в СССР значительная часть населения находилась под непосредственным контролем органов госбезопасности. К марту 1941 года в СССР на списочном учете антисоветских элементов состояли около 1 миллиона 263 тысяч человек ${ }^{33}$.

Наиболее известны факты преследования членов так называемых антипартийных группировок, которые вылились в конечном итоге в известные московские процессы. Впервые органы госбезопасности начали борьбу против членов правящей партии в 1921 году, осуществляя наблюдение за группой членов партии, составивших так называемую «рабочую оппозицию». В период до начала массовых репрессий в 1934 году был арестован 631 человек за принадлежность к оппозиционным политическим партиям (троцкистов и зиновьевцев). В период чистки страны было арестовано почти 62 тысячи троцкистов ${ }^{34}$.

Другим направлением политических репрессий стала ликвидация в 20-е годы партий меньшевиков, эсеров, анархистов и других небольшевистских партий и групп. В 1922 году в Секретном отделе ОГПУ на опера-

32. Там же, ф. 66, оп. 1т., д. 143, лл. 57-57об.

33. Там же, ф. 8ос, оп. 1, д. 81, л. 14.

34. Там же, д. 80, лл. 57-58, 61-62. 
тивном учете состояли немногим более тысячи членов этих партий, проживавших в различных областях советской России.

Отдельные негативные оценки как внешней, так и внутренней политики СССР, полученные в результате перлюстрации органами госбезопасности корреспонденции представителей различных политпартий и бывших оппозиционеров, можно охарактеризовать как проявление пассивного социального протеста. Наиболее активные лидеры не существовавших уже партий эсеров и меньшевиков находились в ссылке и политизоляторах. За 1934-1936 годы, то есть до начала массовых репрессий, были арестованы 1213 человек, как правило, людей, связанных с находившимися в заключении или ссылке членами этих партий. В период массовых репрессий было арестовано почти 38 тысяч эсеров, меньшевиков и анархистов.

На протяжении 1940-1950-х годов наблюдалась общая тенденция резкого снижения количества арестов бывших членов антипартийных групп и представителей небольшевистских партий. Так, например, в 1947 году было арестовано чуть более ста человек. Относительно резкое возрастание репрессий против этой категории населения произошло в послевоенные годы в период обострения международной обстановки, политики «холодной войны». В соответствии с указом Президиума Верховного Совета СССР от 21 февраля 1948 года была издана совместная директива МГБ и Прокуратуры СССР о направлении особо опасных государственных преступников по отбытии наказания в ссылку в отдаленные местности СССР. После отбытия наказания, в связи с тем, что они якобы представляли опасность по своим связям и враждебной деятельности, их рекомендовалось направлять в ссылку на поселение. Вопрос о ссылке решался Особым совещанием при Министерстве государственной безопасности СССР. Все это привело к резкому скачку, не только ссылок, но и арестов. В 1949 году в общей сложности было арестовано более 4 тысяч так называемых троцкистов, правых, меньшевиков, эсеров, анархистов.

\begin{tabular}{|l|r|r|r|c|}
\hline \multicolumn{1}{|c|}{ Арестовано } & 1947 & 1948 & 1949 & 1952 \\
\hline Троцкистов & 93 & 1364 & 3078 & 83 \\
\hline Правых & 6 & 101 & 345 & 2 \\
\hline Меньшевиков & 5 & 174 & 293 & 10 \\
\hline Анархистов & 9 & 46 & 88 & 3 \\
\hline Эсеров & 17 & 256 & 554 & $15^{35}$ \\
\hline Всего & 130 & 1941 & 4358 & 113 \\
\hline
\end{tabular}

Но главным направлением политических репрессий стало преследование советских граждан за антисоветскую агитацию и принадлежность к так

35. Там же, д. 163, 171, 178, 199. 
называемым контрреволюционным организациям. В 1920-1930-е годы сотрудники органов госбезопасности считали эту деятельность своим «главным хлебом». Количество арестованных только за антисоветскую агитацию по статье 58-10 УК РСФСР составляло в разные годы от 14 до $29 \%$ от общего числа арестованных. По некоторым регионам в отдельные годы процент арестованных доходил до $80 \%$.

\begin{tabular}{|c|c|c|c|c|c|}
\hline Арестовано & 1936 & 1940 & 1947 & 1950 & 1952 \\
\hline Всего & 130041 & 132958 & 67237 & 57599 & 16407 \\
\hline $\begin{array}{l}\text { За контрреволюционную } \\
\text { агитацию (с 1941 г. анти- } \\
\text { советская агитация) }\end{array}$ & 21481 & 26240 & 7882 & 12493 & $4249^{36}$ \\
\hline
\end{tabular}

Количество лиц, арестованных за идеологические воззрения, было значительно больше. Так например, в 1940 году за антисоветские высказывания, агитацию, контрреволюционный саботаж, недоносительство было арестовано 30683 человека.

Одиночные высказывания не представляли особой опасности, но в различных слоях советского общества возникали оппозиционные группы и даже небольшие организации, представители которых реально оценивали огромные потери от насильственной коллективизации и форсированной индустриализации. Программные документы этих организаций могли вызвать поддержку у значительной части городского и сельского населения и представляли реальную угрозу для режима в отличие от верхушечной борьбы в высших эшелонах власти. Именно эти группы становились объектом особенно пристального внимания со стороны органов госбезопасности, и информация о них немедленно докладывалась Сталину. В 1934-1936 годах в Красной Армии, в среде городской и сельской интеллигенции Ульяновска, Саратова, Самары и других городов и областей СССР возник целый ряд организаций, которые только начинали пропагандистскую деятельность и не успевали расширить свое влияние, поскольку были быстро ликвидированы органами госбезопасности. При этом четко прослеживается намерение создать два типа нелегальных организаций. Так, члены «Боевого коммунистического союза» в Ленинградской школе военных топографов, члены «Всесоюзной партии экономического возрождения страны» в Саратовской бронетанковой школе ставили своей задачей проведение, по их мнению, подлинно ленинской политики, извращенной Сталиным и его окружением. Однако члены организации в Ульяновске, во главе которой стоял бывший офицер, агроном Найденов составили программу, в которой отменялась руководящая роль коммунистической партии и провозглашалась необходимость создания демократической республики. Подобного рода организации, безусловно, являются значительной вехой в развитии

36. Там же, д. $65,81,163,185,199$. 
демократического движения в СССР. Массовые репрессии привели к тому, что в течение 1939-1941 годов практически исчезли спецсообщения о создании каких-либо групп и организаций, имевших программу переустройства советского общества на демократической основе, хотя стихийные антисоветские выступления продолжались. Возрождение подобных организаций начнется в конце 1940-х — начале 1950-х годов.

Свое главное воздействие на морально-политическое единство общества органы госбезопасности оказывали путем подавления любых проявлений инакомыслия, которое хотя и способствовало определенной политической стабильности, но консервировало все внутренние противоречия, как в сфере политической, так и духовной жизни общества.

Академия Федеральной службы безопасности России Каффедра истории Отечества и органов безопасности

e-mail:karidad@terra.com 